Original Research Article

\title{
Evaluation of zinc as anti-asthma agent: a preclinical study on guinea pigs
}

\author{
Sharanabasayyaswamy B. Hiremath ${ }^{1 *}$, Priya G. ${ }^{2}$
}

${ }^{1}$ Department of Pharmacology, Kodagu Institute of Medical Sciences, Madikeri, Karnataka, India

${ }^{2}$ Department of Pharmacology, SDM Medical College, Dharwad, Karnataka, India

Received: 15 May 2017

Accepted: 24 June 2017

\section{*Correspondence to:}

Dr. Sharanabasayyaswamy B.

Hiremath,

Email: dr.sharan83@yahoo.com

Copyright: (C) the author(s), publisher and licensee Medip Academy. This is an openaccess article distributed under the terms of the Creative Commons Attribution NonCommercial License, which permits unrestricted noncommercial use, distribution, and reproduction in any medium, provided the original work is properly cited

\begin{abstract}
Background: The role of intravenous magnesium sulfate in acute asthma is restricted to severe and resistant cases while that of zinc as prophylactic agent. What is quite interesting is to know the benefits of zinc in acute attack of asthma and that of magnesium as prophylactic agent. The objective of the study was to analyze the bronchodilatory effects of zinc sulfate and prophylactic role of magnesium sulfate using a preclinical model of histamine and acetylcholine induced acute bronchial asthma in conscious guinea pigs.

Methods: Animals were exposed to histamine diphosphate (1\%) and acetylcholine chloride (10\%) aerosols before and after administration of the respective test drugs after acute and sub-acute treatment regimens. Time for onset of preconvulsive dyspnea (PCD) was noted and compared within and between the treatment groups interms of percentage of protection.

Results: Magnesium significantly prolonged time for convulsion compared to control group. But this difference was insignificant when compared with antihistaminic and anticholinergic drugs. Zinc was superior to control and magnesium treatment group in sub-acute treatment study.

Conclusions: Magensium sulfate has bronchodilatory effects but no prophylactic effects while it is vice versa with zinc sulfate.
\end{abstract}

Keywords: Bronchial asthma, Magnesium sulfate, Zinc sulfate

\section{INTRODUCTION}

Bronchial asthma is a chronic inflammatory disease of the airway with recurrent exacerbations or attacks characterized by breathlessness associated with wheeze, cough, tightness in the chest, etc. ${ }^{1,2}$ The prevalence of bronchial asthma in India varies from $3-38 \%$ in children and $2-12 \%$ in adults. ${ }^{2}$ Treatment with inhaled beta-2 agonists and intravenous cortecosteroids is the perhaps effective therapy in most cases of acute exacerbations. Role of aminophylline is limited and addition of ipatropium bromide to beta- 2 agonist is considered to be beneficial. ${ }^{2}$ The use of intravenous magnesium sulfate is restricted to severe and resistant cases owing to its safety issues. ${ }^{2}$ What is quite interesting is to know the benefits of zinc in acute attack of asthma. This is because apart from the evidences of its deficiency in bronchial asthma patients, zinc has shown cellular and molecular level antiasthma effects. ${ }^{3-5}$ Daily supplementation of low dose of zinc was proven to be beneficial at least in terms of reduction in severity of clinical signs and symptoms of bronchial asthma in children. ${ }^{6}$ Unlike zinc, the deficiency of magnesium in asthma patients was not found in a clinical study but has shown the weak but significant effects in treatment of acute asthma. ${ }^{7,8}$ This perhaps indicates the restricted role of magnesium in the treatment of only severe acute exacerbations of asthma. So as per the 
available evidences zinc and magnesium perhaps have different roles in bronchial asthma with zinc having prophylactic role on bronchial epithelium and magnesium having acute bronchodilator effect. It is not clear whether low dose supplementation of magnesium has the prophylactic effects as that of zinc sulfate and whether zinc can be used as alternative to magnesium in treatment of acute attacks of bronchial asthma. This is relevant since the magnesium administration needs to be done under supervision owing to its toxicity profile and to explore whether supplementation of the zinc on daily basis would reduce the severity of asthma. ${ }^{9}$ Hence the present study aims at analyzing the acute bronchodilatory effects of zinc and prophylactic role of magnesium using a preclinical model of histamine and acetylcholine induced acute bronchial asthma in conscious guinea pigs.

\section{METHODS}

T Study was conducted in the central animal house of our institute after the approval from Institutional Animal Ethics Committee. Histamine diphosphate and acetylcholine chloride were purchased from the Sigma Aldrich, Bangalore while salts of magnesium and zinc as sulfates were purchased from the NICE Pharmaceuticals, Bangalore. Sterile distilled water, injection atropine and pheniramine maleate were purchased from local pharmacy. Salt solutions of zinc sulfate and magnesium sulfate were freshly prepared just before administration by dissolving in distilled water. Guinea Pigs of either sex weighing 250-350gms were used for this study. Animals were obtained from central animal house of department of Pharmacology of our institute, kept under standard laboratory conditions with free access to food and water. Thirty animals were selected and randomly divided into five groups, each containing six rats as follows: Distilled Water (control) group, receiving distilled water $(1 \mathrm{ml} / \mathrm{kg}$, i.p); Antihistamine group, receiving injection chlorpheniramine maleate $(2 \mathrm{mg} / \mathrm{kg}$, i.p); Anticholinergic group, receiving atropine $(2 \mathrm{mg} / \mathrm{kg}$, i.p); Magnesium sulfate group and Zinc sulfate group.

All the animals were exposed to histamine diphosphate $(1 \%)$ and acetylcholine chloride $(10 \%)$ aerosols before and after administration of the respective test drugs. Aerosols were generated by the nebulizer machine with constant pressure of $160 \mathrm{~mm} \mathrm{Hg}$ in the histamine chamber. Preconvulsive time (PCT) i.e. time from exposure to aerosols to appearance of convulsions was noted in all animals before and after administration of the drugs. In sub-acute study, same procedure was repeated after fifteen days of treatment with zinc sulfate $(10 \mathrm{mg} / \mathrm{kg} / \mathrm{d})$ and magnesium sulfate $(10 \mathrm{mg} / \mathrm{kg} / \mathrm{d})$ to the animals in zinc group and magnesium group respectively. Animals in control group received distilled water for fifteen days and animals in the standard group did not receive any treatment for fifteen days. The doses of atropine and chlorpheniramine maleate were selected based on the doses used in one of the published study. ${ }^{10}$ Dose of magnesium sulfate $(140 \mathrm{mg} / \mathrm{kg})$ used in acute study is the extrapolated dose used for acute asthma in humans. ${ }^{11}$ Dose of zinc sulfate $(150 \mathrm{mg} / \mathrm{kg})$ used in acute study was the extrapolated dose used in studies screening its antiepileptic effect in rats. ${ }^{12}$ Sub-acute doses of magnesium $(10 \mathrm{mg} / \mathrm{kg} / \mathrm{d})$ and zinc $(10 \mathrm{mg} / \mathrm{kg} / \mathrm{d})$ used for daily administration in sub-acute study were based on the studies screening for their CNS disorders. ${ }^{13,14}$ No antihistamine an anti-cholinergic group was used while screening for the effects of magnesium and zinc in subacute treatment study. Mean and standard deviations values of time for PCT were calculated for each group. The differences in the values of time for PCT before and after administration of drugs within the groups were estimated by using paired t-test. The differences between individual test groups were estimated by unpaired t-test. $\mathrm{P}$ value $<0.05$ was considered as significant difference.

\section{RESULTS}

Tables 1 to 3 shows the effects of different drugs and comparison between them in acute and sub-acute treatment study designs.

Magnesium sulfate at the given doses was significantly better than control treated group in acute study. However, no significant difference was observed when compared with standard treatment groups. Zinc at the given doses has failed to show any significant effects in acute treatment study. In sub-acute treatment study, zinc sulfate was far superior to magnesium as prophylactic agent.

Table 1: Effect of drugs on time for onset of histamine induced pre-convulsive dyspnea.

\begin{tabular}{|c|c|c|c|c|}
\hline & Baseline & After treatment & Difference & P-value \\
\hline \multicolumn{5}{|c|}{ Acute treatment study } \\
\hline Control group & $96.17 \pm 41.77$ & $94.50 \pm 44.42$ & $-1.67 \pm 2.08$ & 0.5540 \\
\hline $\mathrm{ZnSO}_{4}$ group & $108.17 \pm 13.76$ & $95.67 \pm 27.40$ & $-12.50 \pm 15.62$ & 0.2414 \\
\hline $\mathrm{MgSO}_{4}$ group & $104.33 \pm 49.05$ & $143.67 \pm 25.84$ & $39.33 \pm 32.21$ & $0.0112 *$ \\
\hline Antihistamine group & $76.17 \pm 33.98$ & $221.83 \pm 35.74$ & $145.67 \pm 41.41$ & $0.0001 *$ \\
\hline \multicolumn{5}{|c|}{ Sub-acute treatment study } \\
\hline Control group & $96.17 \pm 41.77$ & $95.67 \pm 35.58$ & $0.50 \pm 0.62$ & 0.5407 \\
\hline $\mathrm{ZnSO}_{4}$ group & $108.17 \pm 13.76$ & $390.33 \pm 49.16$ & $-282.17 \pm 60.61$ & $0.0001 *$ \\
\hline $\mathrm{MgSO}_{4}$ group & $104.33 \pm 49.05$ & $122.50 \pm 40.84$ & $-18.17 \pm 23.12$ & 0.5039 \\
\hline
\end{tabular}

*Significant difference. All values are in seconds as mean \pm SD. P-value using paired t-test 
Table 2: Effect of drugs on time for onset of acetylcholine induced pre-convulsive dyspnea.

\begin{tabular}{|c|c|c|c|c|}
\hline & Baseline & After Treatment & Difference & P-value \\
\hline \multicolumn{5}{|l|}{ Acute treatment study } \\
\hline Control group & $25.00 \pm 4.60$ & $28.33 \pm 6.35$ & $3.33 \pm 4.16$ & 0.1324 \\
\hline $\mathrm{ZnSO}_{4}$ group & $26.00 \pm 4.43$ & $29.83 \pm 8.54$ & $3.83 \pm 4.78$ & 0.2519 \\
\hline $\mathrm{MgSO}_{4}$ group & $23.33 \pm 8.09$ & $62.67 \pm 16.32$ & $39.33 \pm 17.19$ & $0.0007^{*}$ \\
\hline Anticholinergic group & $20.67 \pm 3.93$ & $148.33 \pm 23.71$ & $127.67 \pm 31.80$ & $0.0001 *$ \\
\hline \multicolumn{5}{|c|}{ Sub-acute treatment study } \\
\hline Control group & $25.00 \pm 4.60$ & $24.67 \pm 2.66$ & $0.33 \pm 0.41$ & 0.7711 \\
\hline $\mathrm{ZnSO}_{4}$ group & $26.00 \pm 4.43$ & $45.0 \pm 2.83$ & $-19.0 \pm 5.81$ & $0.0001 *$ \\
\hline $\mathrm{MgSO}_{4}$ group & $23.33 \pm 8.09$ & $27.0 \pm 6.63$ & $-3.67 \pm 4.59$ & 0.4683 \\
\hline
\end{tabular}

*Significant difference. All values are in seconds as mean \pm SD. P-value using paired t-test

Table 3: Group wise comparison of mean difference in onset of pre-convulsive dyspnea between individual groups.

\begin{tabular}{|c|c|c|c|c|}
\hline & Histamine & P-value & Acetylcholine & P-value \\
\hline \multicolumn{5}{|l|}{ Acute treatment } \\
\hline Control vs $\mathrm{ZnSO}_{4}$ & $10.83 \pm 13.53$ & 0.1232 & $-0.50 \pm 0.62$ & 0.8506 \\
\hline Control vs $\mathrm{MgSO}_{4}$ & $-41.00 \pm 36.69$ & $0.0110 *$ & $-36.00 \pm 20.10$ & $0.0005 *$ \\
\hline Control vs Antihistamine & $-147.37 \pm 47.14$ & $0.0001 *$ & - & - \\
\hline Control vs Anticholinergic & - & - & $-124.34 \pm 36.46$ & $0.0001^{*}$ \\
\hline $\mathrm{Zn} \mathrm{SO}_{4} \mathrm{vs} \mathrm{MgSO}_{4}$ & $-51.83 \pm 40.69$ & $0.0053 *$ & $-35.50 \pm 20.27$ & $0.0006^{*}$ \\
\hline $\mathrm{Zn} \mathrm{SO}_{4}$ vs Antihistamine & $-158.17 \pm 50.30$ & $0.0001 *$ & - & - \\
\hline $\mathrm{Zn} \mathrm{SO}_{4}$ vs Anticholinergic & - & - & $-123.84 \pm 36.56$ & $0.0001^{*}$ \\
\hline $\mathrm{Mg} \mathrm{SO}_{4}$ vs Antihistamine & $-106.34 \pm 59.64$ & $0.0006^{*}$ & - & - \\
\hline $\mathrm{Mg} \mathrm{SO}_{4}$ vs Anticholinergic & - & - & $-88.34 \pm 41.09$ & $0.0001 *$ \\
\hline \multicolumn{5}{|l|}{ Sub-acute treatment } \\
\hline Control vs $\mathrm{ZnSO}_{4}$ & $282.67 \pm 68.73$ & $0.0001 *$ & $19.33 \pm 6.62$ & $0.0001 *$ \\
\hline Control vs $\mathrm{MgSO}_{4}$ & $18.67 \pm 23.33$ & 0.0762 & $4.00 \pm 4.99$ & 0.0594 \\
\hline $\mathrm{Zn} \mathrm{SO}_{4} \mathrm{vs} \mathrm{MgSO}_{4}$ & $264.00 \pm 40.69$ & $0.0001 *$ & $-15.33 \pm 8.41$ & $0.0005^{*}$ \\
\hline
\end{tabular}

*Significant difference. All values are in in seconds as mean \pm SD. P-value using unpaired t-test

\section{DISCUSSION}

Results of our study suggest that magnesium sulfate is more efficacious than placebo and zinc sulfate but not superior to antihistamines or anticholinergics in treatment of acute attacks of bronchial asthma. With regard to prophylactic effects zinc was far superior to magnesium and control group. On comparision of these results of zinc with the acute study results of antihistamines and anticholinergics treated groups, it appears that the zinc is non-inferior to standard antihistamines and anticholinergics. It is quite difficult for us to attribute this observation to bronchodilator effects of the zinc sulfate since the animals in zinc sulfate treated group still showed some amount of mild dyspnea but it took significant time for them to have convulsions. Unlike in antihistamine and anti-cholinergic treated groups where the onset of dyspnea itself was delayed, in zinc sulfate treated groups it was the onset of convulsions that was delayed. It perhaps points at the anti-convulsant effects of zinc sulfate rather than bronchodilator effects. ${ }^{12}$ Since the available evidences justify prophylactic role of zinc in asthma, it is possible that the mild amount of dyspnea in zinc sulfate treated group may represent this effect.

The differences in the observed effects of zinc and magnesium could be explained on the basis of their different mechanisms of actions on the respiratory track and its epithelium. Magnesium effects are supposed to be mediated by smooth muscle relaxation by modulating influx of calcium ions. ${ }^{15,16}$ In addition, minor effects like inhibition of local histamine, acetylcholine, superoxides release during the acute exacerbations of asthma have also been proposed to be responsible for its bronchodialtor effects and thus make it suitable for the acute treatment of bronchial asthma. ${ }^{15,16}$ On the contrary, the antiinflammatory, anti-apoptotic effects of zinc on respiratory epithelium rather than smooth muscles of the respiratory tract make it a better prophylactic agent than a bronchodilator drug. ${ }^{3,4}$ However, our idea behind screening bronchodilator effect of zinc in acute attack of asthma was based on the inhibitory effect of magnesium on NMDA receptors. Relaxation of the smooth muscles by inhibition of calcium channels by magnesium is basically an indirect effect mediated through inhibition of NMDA 
receptors. ${ }^{16}$ Since zinc also has NMDA receptor inhibitory activity and we thought that perhaps zinc might also be having bronchodilator effects. ${ }^{17}$ Our hypothesis was further supported by the fact that the NR1 subunit of NMDA receptor inhibited by zinc is expressed in the respiratory smooth muscles rather than on the respiratory epithelium. ${ }^{18}$ Further, unlike neuronal NMDA receptors, where both potentiating or inhibition of the receptor may occur depending on the neuronal activity, the receptors in respiratory smooth muscles are only inhibited. ${ }^{19}$

Other significant change observed after sub-acute treatment of zinc sulfate was the generalized depression, reduced motor activity with slow and shallow respiratory movements after removal of animals from the histamine chamber. This might represent the CNS depressant activity and its direct cardiac suppressant activity at the dose we used in our study. ${ }^{20}$ Animals recovered after giving rescue doses of antihistamine and atropine. Possibility of high risk of respiratory centre depression and direct cardiac depressant effect can be a major drawback for use of zinc sulfate. We would like to highlight that this is just a hypothesis and needs further studies. In addition, since we did not see such effects in one of our previous study on anti-convulsant activity of zinc in albino rats, we cannot extrapolate the effects to other animals. With the available results, efficacy and safety of zinc sulfate as an alternative to magnesium sulfate in treatment of acute asthma cannot be confirmed and needs further studies on non-rodent animal models. To conclude, magnesium sulfate is effective anti-astmatic agent in acute attacks rather than as a prophylactic agent while use of zinc sulfate perhaps should be restricted to prophylaxis rather than for treatment of acute attacks. There is a need for further studies elucidating the possible toxicities associated with acute high dose treatment of zinc sulfate.

Funding: No funding sources

Conflict of interest: None declared

Ethical approval: The study was approved by the Institutional Ethics Committee

\section{REFERENCES}

1. Koul PA, Patel D. Indian guidelines for asthma: Adherence is the key. Lung India. 2015;32(S1):1-2. Available http://www.lungindia.com/article.asp?issn=0970-

2113; year $=2015$; volume $=32 ;$ issue $=7$; page $=1$; epage $=$ 2; aulast=Koul.

2. Rai CSP, Patil CAP, Lt Vardhan CV, Marwah MV, Pethe M, Pandey MIM. Best Treatment Guidelines For Bronchial Asthma. MJAFI. 2007;63:264-8. Available at:

http://scialert.net/qredirect.php?doi=jms.2015.122.12 9\&linkid=pdf.

3. Khanbabaee G, Omidian A, Imanzadeh F, Adibeshgh F, Ashayeripanah M, Rezaei N. Serum level of zinc in asthmatic patients: a case-control study. Allergol
Immunopathol (Madr). 2014;42(1):19-21. Available at: https://www.ncbi.nlm.nih.gov/pubmed/23312452.

4. Truong-Tran AQ, Grosser D, Ruffin RE, Murgia C, Zalewski PD. Apoptosis in the normal and inflamed airway epithelium: role of zinc in epithelial protection and procaspase-3 regulation. Biochem Pharmacol. 2003;66(8):1459-68. Available at: https://www.ncbi.nlm.nih.gov/pubmed/14555222.

5. Lu H, Xin Y, Tang Y, Shao G. Zinc suppressed the airway inflammation in asthmatic rats: effects of zinc on generation of eotaxin, MCP-1, IL-8, IL-4, and IFN$\gamma$. Biol Trace Elem Res. 2012;150(1-3):314-21. Available at: http://link.springer.com/article/10.1007\%2Fs12011012-9493-7.

6. Ghaffari J, Khalilian A, Salehifar E, Khorasani E, Rezaii MS. Effect of zinc supplementation in children with asthma: a randomized, placebo-controlled trial in northern Islamic Republic of Iran. East Mediterr Health J. 2014;20(6):391-6.

7. Powell CV. The role of magnesium sulfate in acute asthma: does route of administration make a difference?. Curr Opin Pulm Med. 2014;20(1):103-8. Available at: https://www.ncbi.nlm.nih.gov/pubmed/24960516.

8. Sein HH, Whye LC, Juan LK, Sl Ng J, Rahardjai A, Sultan MA. Relationship between Intracellular Magnesium Level, Lung Function, and Level of Asthma Control in Children with Chronic Bronchial Asthma. Malays J Med Sci. 2014;21(5):30-6. Available https://www.ncbi.nlm.nih.gov/pubmed/25977631.

9. Lu JF, Nightingale $\mathrm{CH}$. Magnesium sulfate in eclampsia and pre-eclampsia: pharmacokinetic principles. Clin Pharmacokinet. 2000;38(4):305-14. Available https://www.ncbi.nlm.nih.gov/pubmed/10803454.

10. Patil SD, Ahale SV, Surana SJ. Evaluation of antiasthmatic and antianaphylactic activity of balanites aegyptiaca (delile), (balanitaceae). Asian journal of pharmaceutical and clinical research. 2011;4(1):52-5. Available at: http://www.ajpcr.com/Vol4Issue1/146.pdf.

11. Rowe BH, Bretzlaff JA, Bourdon C, Bota GW, Camargo CA. Intravenous magnesium sulfate treatment for acute asthma in the emergency department: a systematic review of the literature. Ann Emerg Med. 2000;36:181-90. Available at: https://www.ncbi.nlm.nih.gov/pubmed/10969218.

12. Hiremath SB, Kamdod MA. Evaluation of Anticonvulsant Activity of Zinc in Albino Rats. Journal of Applied Pharmaceutical Science. 2012;2(9):119-21. Available at: http://www.japsonline.com/admin/php/uploads/644_ pdf.pdf.

13. Bartlomiej P, Sowa-Kucma M, Katarzyna K, Paulina M, Gabriel N, Bernadeta S. Antidepressant-like activity of magnesium in the olfactory bulbectomy model is associated with the AMPA/BDNF pathway. 
Psychopharmacology. 2015;232:355-67. Available at: https://www.ncbi.nlm.nih.gov/pubmed/25027582.

14. Franco JL, Posser T, Brocardo PS, Trevisan R, UlianoSilva $\mathrm{M}$, Gabilan $\mathrm{NH}$, et al. Involvement of glutathione, ERK1/2 phosphorylation and BDNF expression in the antidepressant-like effect of zinc in rats. Behav Brain Res. 2008;188(2):316-23. Available at: https://www.ncbi.nlm.nih.gov/pubmed/18191237.

15. Kelly W. Magnesium Sulfate for Severe Acute Asthma in Children. J Pediatr Pharmacol Ther. 2003;8:40-5. Available https://www.ncbi.nlm.nih.gov/pubmed/23300395

16. Fawcett WJ, Haxby EJ, Male DA. Magnesium: physiology and pharmacology. $\mathrm{Br} \mathrm{J}$ Anaesth. 1999;83(2):302-20. Available at: https://www.ncbi.nlm.nih.gov/pubmed/10618948.

17. Paoletti P, Ascher P, Neyton J. High-Affinity Zinc Inhibition of NMDA NR1-NR2A Receptors. The Journal of Neuroscience. 1997;17(15):5711-25. Available at: https://www.ncbi.nlm.nih.gov/pubmed/9221770.
18. Anaparti V, Ilarraza R, Orihara K, Stelmack GL, Ojo OO, Mahood TH, et al. NMDA receptors mediate contractile responses in human airway smooth muscle cells. Am J Physiol Lung Cell Mol Physiol. 2015;308(12):L1253-64. Available at: https://www.ncbi.nlm.nih.gov/pubmed/25888577.

19. Horning MS, Trombley PQ. Zinc and copper influence excitability of rat olfactory bulb neurons by multiple mechanisms. J Neurophysiol. 2001;86(4):1652-60. Available https://www.ncbi.nlm.nih.gov/pubmed/11600628

20. Powell S, Saltman P, Uretzky G, Chevion M. The effect of zinc on reperfusion arrhythmias in the isolated perfused rat heart. Free Radic Biol Med. 1990;8(1):33-46. Available at: https://www.ncbi.nlm.nih.gov/pubmed/2323582.

Cite this article as: Hiremath SB, Priya G.

Evaluation of zinc as anti-asthma agent: a preclinical study on guinea pigs. Int J Basic Clin Pharmacol 2017;6:1943-7. 